\title{
Health risk behavior pattern among students from Cartagena, Colombia: prevalence and associated variables
}

\author{
PADRÃO DE COMPORTAMENTO DE RISCO PARA A SAÚDE EM ESTUDANTES DE \\ CARTAGENA, COLÔMBIA: PREVALÊNCIA E VARIÁVEIS ASSOCIADAS
}

\author{
PATRÓN DE COMPORTAMIENTO DE RIESGO PARA LA SALUD EN ESTUDIANTES \\ DE CARTAGENA, COLOMBIA: PREVALENCIA Y VARIABLES ASOCIADAS
}

\section{Zuleima Cogollo ${ }^{1}$ Edna Margarita Gómez-Bustamante²}

\begin{abstract}
The aim of the study was to determine the prevalence and variables associated with the pattern of risky health behavior (PRHB) among adolescent students in Cartagena, Colombia. A cross-sectional study was designed to investigate PRHB in a random cluster sample of students from middle and high schools. The associations were adjusted by logistic regression. A total of 2,625 students participated in this research, with ages from 10 to 20 years, mean $=13.8$ years $(S D=2.0)$, and $54.3 \%$ were women. A total of 332 students reported PRHB $(12.7 \%, 95 \% \mathrm{Cl}$ 11.4-14.0). Age over 15 years (OR=2.19, $95 \% \mathrm{Cl} 1.72-2.79)$, not being heterosexual (OR=1.98, 95\% Cl 1.36-2.87), poor/mediocre academic performance $(\mathrm{OR}=1.87$, $95 \% \mathrm{Cl} 1.47-2.38)$, family dysfunction (OR=1.78, 95\% Cl 1.40-2.28) and male gender (OR=1.58, 95\% Cl 1.24-2.01) were associated with PRHB. One in every eight students presented a PRHB. It is important to pay greater attention to students who are over 15 years of age, male, not heterosexual, with a poor/mediocre academic performance and a dysfunctional family.
\end{abstract}

\section{DESCRIPTORS}

Adolescent

Students

Health knowledge, attitudes, practice

Adolescent health

Cross-sectional studies

\section{RESUMO}

O objetivo deste estudo foi determinar a prevalência e as variáveis associadas ao Padrão de Comportamento de Risco para a Saúde (PCRS) entre estudantes adolescentes em Cartagena, Colômbia. Desenhou-se um estudo transversal para investigar o PCRS numa amostra aleatória grupal de estudantes de educação secundária. As associações foram ajustadas mediante regressão logística. Participaram da pesquisa 2625 estudantes entre 10 e 20 anos, numa média $=13.8$ anos ( $D P=2.0$ ) sendo que $54,3 \%$ eram do sexo feminino. Do total de alunos pesquisados 332 (\%) estudantes reportaram PRHP. Do total dos 332 estudantes reportaram PCRS $(12,7 \%$, IC95\% 11.4-14.0). A idade acima dos 15 anos (OR=2,19, IC95\% 1.72-2.79), a condição não heterossexual (OR=1,98, IC95\% 1.36-2.87), o desempenho acadêmico pobre-medíocre (OR=1,87, IC95\% 1.47-2.38), a disfunção familiar (OR=1.78, IC95\% 1.40-2.28) e o sexo masculino (OR=1.58, IC95\% 1.24-2.01) associaram-se ao PCRS. Os resultados indicam que um de cada oito estudantes apresenta PRHP. Deve-se prestar mais atenção aos estudantes acima de 15 anos, homens, não heterossexuais, com um desempenho acadêmico pobre e com famílias disfuncionais.

\section{DESCRITORES \\ Adolescente \\ Estudantes \\ Conhecimentos, atitudes e prática em saúde \\ Saúde do adolescente \\ Estudos transversais}

\section{RESUMEN}

El objetivo del estudio fue determinar la prevalencia y las variables asociadas al Patrón de Comportamiento de Riesgo para la Salud (PCRS) entre estudiantes adolescentes de Cartagena, Colombia. Se diseñó un estudio transversal que investigó el PCRS en una muestra aleatoria de estudiantes de colegios de secundaria. Las asociaciones fueron ajustadas mediante la regresión logística. Participaron 2.625 estudiantes entre 10 y 20 años, promedio=13,8 años ( $D E=2,0)$, de los cuales $54,3 \%$ eran mujeres. Del total de alumnos investigados 332 estudiantes informaron PCRS (12,7\%; IC95\% 11,4-14,0). Edad mayor de 15 años (OR=2,19; IC95\% $1,72-2,79)$, no heterosexuales ( $O R=1,98$; IC95\% 1,36-2,87), el rendimiento académico pobre-mediocre (OR=1,87; IC95\% 1,47$2,38)$, familia disfuncional ( $O R=1,78$; IC95\% $1,40-2,28)$ y sexo masculino (OR=1,58; IC95\% 1,24-2,01) se asociaron a PCRS. Los resultados afirman que uno de cada ocho estudiantes presenta PCRS. Es importante prestar mayor atención a estudiantes mayores de 15 años, varones, no heterosexuales, con $\mathrm{mal} /$ regular rendimiento académico $y$ familia disfuncional.

\section{DESCRIPTORES \\ Adolescente \\ Estudiantes \\ Conocimientos, actitudes y prácticas en salud Salud del adolescente \\ Estudios transversales}

\footnotetext{
${ }^{1}$ Nurse, Master in Public Health. Titular professor, Research Group on Community Health, Nursing School, University of Cartagena, Cartagena, Colombia. zcogollom@unicartagena.edu.co. ${ }^{2}$ Nurse, Master in Nursing, Associate professor, Research Group on Community Health, Nursing School, University of Cartagena, egomezb@unicartagena.edu.co

$\begin{aligned} \text { Rev Esc Enferm USP } & \text { Recebido: 11/06/2012 } \\ \text { 2013; 47(4):830-5 } & \text { Aprovado: 10/09/2012 } \\ \text { www.ee.usp.br/reeuspl } & \text { Português / Inglês }\end{aligned}$
}




\section{INTRODUCTION}

There is an urgent need for professionals from different fields to identify and evaluate health-risk behavior (HRB) that may negatively affect physical growth and mental development in teenagers.

Adolescent HRB can have positive or negative and shortor long-term implications ${ }^{(1)}$. Smoking, alcohol abuse, illegal substances, physical inactivity etc. all have a negative effect on health and tend to increment health risk behavior pattern (HRBP), which increase significantly during adolescence and persist during adulthood ${ }^{(2)}$.

In adolescents, HRBP is complex, and is related to constitutional and environmental variables. For instance, HRBP is explained by certain underlying personality features, such as sensation seeking or pain avoiding. These characteristics are augmented during this stage of the lifecycle. Then, HRBP constitutes a public health problem in both adolescents and older persons. However, very little has been documented on the phenomenon. In the US, Weller et al. evaluated HRB in high school students aged 14-20 and reported that $35.9 \%$ showed signs of HRBP (four to six behaviors). HRBP was more prominent among the young men than the young women ${ }^{(3)}$. In Japan, it was observed that $6.9 \%$ of a sample of students aged 15-18 presented with HRBP (three to eight behaviors). This behavioral pattern was similar among men and women, but increased with the level of schooling ${ }^{(4)}$. In Colombia, HRBP (three to five behaviors) was reported in $21.2 \%$ of a group of $13-19$-year-old state school students in Cartagena. This was significantly associated with male gender, low levels of religiosity and the presence of clinically meaningful depressive symptoms ${ }^{(5)}$. However, the design of the investigation did not allow for generalization in terms of the city's entire teenage population ${ }^{(6)}$.

Undoubtedly, it is more important to know the frequency of HRBP and some of the associated variables, than the prevalence of individual HRBs in a representative sample of students in Cartagena, given the general consensus that it is more important to promote a healthy lifestyle as opposed to preventing specific behaviors, such as smoking or using illegal drugs ${ }^{(7)}$.

The aim of this study was to understand the prevalence of and some of the variables associated with HRBP in teenage students in Cartagena, Colombia.

\section{METHOD}

This was a cross-sectional analytical observational study and was approved by the Ethical Board of Cartagena University. All parents and legal guardians of the participating students gave their consent, and the students themselves agreed to participate. The study followed Colombian norms on health research.

\section{Sample}

For an expected prevalence of $20 \%$ HRBP, an error margin of $2 \%$ and an alpha error of $5 \%$, a sample of 1537 middle- and high-school students was required ${ }^{(8)}$. However, to estimate precise confidence intervals $(\mathrm{Cl})$ the number of participants was overestimated $^{(8)}$, and 130 conglomerates were chosen at random. It was expected that each conglomerate would be made up of approximately 35 students. This number included all losses suffered due to a variety of reasons, and included students between 10 and 20 years old who agreed to participate. The World Health Organization's definition of 'adolescent' was taken as the criterion. Students who did not complete all questionnaires were excluded from the final analysis.

\section{Measures}

The questionnaire included socio-demographic data such as age at the time the survey was undertaken, level of schooling, neighborhood of residence and socioeconomic status, as well as some demographic information regarding the parents. The following were also used: the General Well-Being Index (WHO-5) ${ }^{(9)}$, the Rosenberg self-esteem scale ${ }^{(10)}$, the SCOFF questionnaire for the screening of eating behavior (SCOFF) ${ }^{(11)}$, level of physical activity ${ }^{(12)}$, smoking, the CAGE questionnaire for the screening of alcohol dependence (CAGE) $)^{(13)}$, the VESPA questionnaire for the screening of substance abuse (VESPA) $)^{(14)}$, perception of academic achievement and perception of health over the last month ${ }^{(15)}$, the Francis Scale of Attitude toward Christianity short-form (Francis-5) (16), and sexual behavior and orientation and the family APGAR (family APGAR) ${ }^{(17)}$.

The WHO-5 is made up of five items that evaluate basic clinical manifestations of a major episode of depression over the past 15 days. From a scale of 15 possible scores, the top five are considered clinically significant depressive symptoms ${ }^{(9)}$. The scale shows acceptable internal consistency in teenage students in Cartagena ${ }^{(18)}$.

The Rosenberg self-esteem scale is made up of 10 points with a ordinal-type response pattern and a scale of $0-20^{(10)}$. Scores of 13 and below were classified as low self-esteem. This scale shows acceptable internal consistency in the teenage population ${ }^{(18)}$.

The SCOFF survey quantifies eating patterns during the past 3 months. It is made up of five dichotomous questions that require a yes/no response. A point is given for each positive answer and scores of 2 or above are considered suggestive of a possible eating disorder (anorexia, bulimia or unspecified)(11). This questionnaire was used among female high school students in Bucaramanga, Colombia ${ }^{(19)}$. 
The level of physical activity was evaluated using the Risk Behavior Survey by the Center for Disease Control and Prevention. Physical inactivity was described as anything less than 3 days of physical activity to strengthen or tone the muscles (sit-ups, push-ups, weights or any other gym activity) in the past week $^{(12)}$.

Smoking was evaluated using questions such as whether the students had ever smoked, whether they had smoked in the past month, and whether they had smoked on a daily basis over the past month. Those who said they had smoked on a daily basis over the past month were considered smokers. This was based on the criteria for nicotine dependence proposed by the Diagnostic and Statistical Model for Mental Disorders of the American Psychiatric Association 4th edition, revised (DSM-IV-TR) and the World Health Organization in the International Classification of Mental and Behavioral Diseases 10th edition (ICD-10).

The CAGE questionnaire studies the risk of abusive alcohol consumption and includes four questions regarding self-blame, social criticism, and the need to reduce alcohol consumption in the morning. Each affirmative answer is worth one point. Scores of 2 or more suggest a level of alcohol dependency ${ }^{(13)}$. The scale shows acceptable psychometric performance in teenage students in Cartagena ${ }^{(18)}$.

The VESPA questionnaire studies substance abuse. A modified version of form 1 of the Epidemiology Surveillance System for Psychoactive Substance Abuse, commonly used in Colombia, was used for this study. The only part of the form used was the section dealing with the use of ecstasy, cannabis, cocaine paste, cocaine and other substances (inhaler, sleeping tablets or tranquilizers). It also studies the subjective perception of health and academic performance during the past month ${ }^{(14)}$.

The Francis- 5 Scale consists of five items that evaluate the affective response to thoughts of God, Jesus and prayer. The point system is from 0 to $20^{(16)}$. Points equal to or higher than 19 were considered to show high levels of religiosity. This version showed internal consistency among students in Cartagena ${ }^{(18)}$.

To measure sexual orientation and behavior, the teenagers were asked whether penetration was involved in their first sexual experience with another person, and what age they were when that took place. They were also asked what their sexual orientation was according to the American Psychiatric Association.

The family APGAR qualifies family functionality using five ordinal-type items that explore the personal perception of family functionality (adaptability, partnership, growth, affection and resolve) over the past 6 months. Points equal to or less than 15 suggest a dysfunctional family ${ }^{(17)}$. The questionnaire showed high reliability among students in Cartagena ${ }^{(18)}$.

\section{Procedure}

Each student filled out her or his questionnaire in her or his own classroom supervised by the person assigned (final-semester trainee nurses), who had previously collected the parents' consent forms, explained the goals of the study and asked for voluntary participation. All questions were to be answered fully and honestly, with confidentiality guaranteed.

Each student was given the questionnaire in an envelope and had to complete it using a black pencil and an eraser. Once finished, they had to place the questionnaire in the envelope and return it to the supervisor.

\section{Statistical analysis}

The HRBP (three or more of the six risk behaviors, even though sexual relations in themselves do not constitute a health risk) was taken as the dichotomous dependent variable (present or absent). The demographic variables, general well-being, self-esteem, perception of academic performance over the past month, perception of health over the past month, religiosity, sexual orientation and family functionality were managed as independent dichotomous variables.

Frequencies and percentages were determined for the categorical variables. Similarly, for the HRBP the $\mathrm{Cl}$ was calculated at $95 \%$. Averages with standard deviation were determined for quantitative data such as age. The bivariate analysis explored the association between the different variables and the presence of HRBP by estimating the odds ratio (OR) with $95 \% \mathrm{Cl}$.

Associations with a type I error $<20 \%$ were considered for inclusion in the multivariate model. Greenland guidelines were used for the analysis ${ }^{(19)}$ and the OR and $95 \% \mathrm{Cl}$ were determined. The Hosmer-Lemeshow goodness-of-fit-test ${ }^{(20)}$ was applied to the final model, and the data were analyzed using the statistics package STATA 9.0 (21).

\section{RESULTS}

The number of participating students was 2625; they were aged between 10 and 20 years, mean $13.8(S D=2.0)$; there were 1585 students aged $10-15$ years (60.4\%); female gender 1425 (54.3\%); basic high-school 1777 (67.7\%); low socioeconomic status 1911 (72.8\%); state school 1817 (69.2\%); heterosexual orientation 2411 (91.9\%); no experience of sexual relations 2038 (77.6\%); perception of good or excellent health $2176(82.9 \%)$; good or excellent academic performance 1876 (71.5\%); high religiosity 1766 (67.3\%); high self-esteem 1421 (54.1\%); symptoms of clinical depression 189 (7.2\%); and dysfunctional family 1259 (48.0\%).

A total of 332 students presented some degree of HRBP (12.7\%; $95 \% \mathrm{Cl} 11.4-14.0)$. The frequency of each HRB can be seen in Table 1, which shows a high level of physical inactivity and a low frequency of smoking over the past month. The scales showed the following internal consistencies: APGAR, 0.770; Rosenberg, 0.574; SCOFF, 0.386; WHO-5, 0.750; CAGE, 0.567; and Francis-5, 0.915.
Health risk behavior pattern among students from Cartagena, Colombia: prevalence and associated variables Cogollo Z, Gómez-Bustamante EM 
Table 1 - HRB Frequency among Teenage Students in Cartagena, Colombia

\begin{tabular}{lcc}
\hline Variables & N & \% \\
\hline Smoking over the last month & 101 & 3.8 \\
Alcohol abuse over the last month & 232 & 8.8 \\
Substance abuse over the last month & 207 & 7.9 \\
Risk of eating disorder & 852 & 32.5 \\
Physical inactivity & 1900 & 72.4 \\
Has had sexual relations at some point in life & 587 & 22.4 \\
\hline
\end{tabular}

The bivariate analysis showed an association between low socioeconomic status and studying in state school with HRBP. Socioeconomic status showed a probability of $<0.20$ and was not considered in the multivariate analysis. The $O R$ and $95 \% \mathrm{Cl}$ are presented in Table 2 . All the variables shown in Table 2 were considered in the multivariate analysis, except the variable socioeconomic status.

Table 2 - Variables Associated with HRBP among Teenage Students in Cartagena, Colombia

\begin{tabular}{lcc}
\hline Variables & OR & $\mathbf{9 5 \% ~ C I ~}$ \\
\hline Age 16-20 years & 2.34 & $1.85-2.95$ \\
Male gender & 1.75 & $1.38-2.21$ \\
Part-time vocational & 2.00 & $1.58-2.52$ \\
Socioeconomic status: high & 1.18 & $0.92-1.52$ \\
State school & 1.22 & $0.95-1.58$ \\
Not heterosexual & 1.78 & $1.25-2.56$ \\
Perception of bad or not-so-good health & 1.50 & $1.13-1.98$ \\
Bad or not-so-good academic performance & 2.20 & $1.74-2.78$ \\
Low religiosity & 1.60 & $1.26-2.02$ \\
Low self-esteem & 1.39 & $1.10-1.75$ \\
Symptoms of clinical depression & 1.64 & $1.11-2.45$ \\
Dysfunctional family & 2.04 & $1.61-2.59$ \\
\hline
\end{tabular}

The variables that stayed in the significant association range are shown in Table 3. Age and sexual orientation showed the highest association.

Table 3 - Multivariate Model for HRBP among Teenage Students in Cartagena, Colombia

\begin{tabular}{lcc}
\hline Variables & OR & 95\% CI \\
\hline Age 16-20 years & 2.19 & $1.72-2.79$ \\
Not heterosexual & 1.98 & $1.36-2.87$ \\
Bad or not-so-good academic performance & 1.87 & $1.47-2.38$ \\
Dysfunctional family & 1.78 & $1.40-2.28$ \\
Male & 1.58 & $1.24-2.01$ \\
\hline
\end{tabular}

Hosmer-Lemeshow goodness-of-fit-test: Chi-squared=11.42; degree of freedom $=10$; probability $=0.179$.

\section{DISCUSSION}

This study found that HRBPs were reported by $12.7 \%$ of the students. The variables most associated with HRBP were: age 15, male gender, not heterosexual, bad-to-average academic performance, and dysfunctional family.

The prevalence of HRBP varies greatly from one study to another, depending on the population studied and the definition of HRBP. This study showed that $12.7 \%$ of the students showed signs of HRBP. The percentage is significantly higher than the $6.9 \%$ reported among students in Japan ${ }^{(4)}$. However, it is inferior to the $21.2 \%$ found in students in Cartagena, Colombia ${ }^{(5)}$ and the $35.9 \%$ documented for teenagers in vocational schools in the US ${ }^{(3)}$.

Similarly, the variables associated with HRBP showed some variation according to the study. The variables age 15, male gender, not heterosexual, bad-to-average academic performance and dysfunctional family have a significant association with HRBP. However, these findings show discrepancies with previous studies. Several researchers reported that HRBP occurs more frequently in men than in women ${ }^{(3,5)}$, but others found that the frequency was comparable, independent of gender ${ }^{(4)}$.

It is important to point out that in this study low religiosity and symptoms of clinical depression were independent of HRBP. However, in a previous study undertaken among state school students in Cartagena, Colombia, it was observed that low religiosity and symptoms of clinical depression were associated with HRBP(5). It may be possible to explain these differences as being due to the characteristics of the participants in each of the studies. The research included students aged 13-19 and, in defining HRBP, students were only asked to report sexual relations they may have had before the age of 13, and not the pattern of physical activity ${ }^{(5)}$. Future studies will need to confirm such observations with a similar definition for $\mathrm{HRBP}^{(6)}$.

HRBP must be thought of as a complex public health issue in which there are a number of interacting elements with relation to the participants themselves, their families, community, culture and general society. It is important to bear in mind that in adolescents, problem behavior usually appears in clusters and not as a unique specific behavior. It is evident that preventing and dealing with HRBP in teenagers demands an integrated approach ${ }^{(1)}$. The information about health risk behaviors among adolescents is interesting for nursing actions, from a standpoint of integral health. This is crucial, as during adolescence people report a low perception of risk. The nursing profession has a very important role to play when it comes to promoting healthy lifestyles and educating people. In addition, nurses can help with respect to the early identification of possible cases of HRBP(2). 
It is important not to underestimate HRB in adolescence, or to view it as a temporary event which will disappear once the teenager 'grows out of it'. It is obvious that these behaviors continue throughout adult life, negatively affecting people's well-being. The promotion of a healthy lifestyle must begin in childhood, with special emphasis in adolescence and early adulthood, which is when HRB becomes consolidated ${ }^{(7)}$.

This study is solid in that it was undertaken with the participation of a large representative group in Cartagena, and many variables associated with HRBP were explored both theoretically and empirically; nevertheless, the cross-sectional design limits the possibility of affirming a causal direction. Future longitudinal studies may produce information that is pertinent to the direction of association ${ }^{(6)}$.

\section{REFERENCES}

1. Faeh D, Viswaathan B, Chiolero A, Warren W, Bovet P. Clustering of smoking, alcohol drinking and cannabis use in adolescents in a rapidly developing country. BMC Public Health. 2006;6:169.

2. Ferreira MM, Torral MC. Life styles in adolescence: sexual behavior of Portuguese adolescents. Rev Esc Enferm USP [Internet]. 2011 [cited 2011 Aug 25];45(3):588-94. Available from: http://www.scielo.br/pdf/reeusp/v45n3/ en_v45n3a06.pdf

3. Weller NF, Tortolero SR, Kelder SH, Grunbaum JA, Carvajal SC, Gingiss PM. Health risk behaviors of Texas students attending dropout prevention/recovery schools in 1997. J Sch Health. 1999;69(1):22-8.

4. Takakura M, Nagayama T, Sakihara S, Willcox C. Patterns of health-risk behavior among Japanese high school students. J Sch Health. 2001;71(1):23-9.

5. Campo-Arias A, Cogollo Z, Díaz CE. Comportamientos relacionados con la salud en adolescentes estudiantes: prevalencia y factores asociados. Salud Uninorte. 2008;24(2):224-36.

6. Grimes DA, Schulz KF. An overview of clinical research: the lay of the land. Lancet. 2002;359(9300):57-61.

7. Brody GH, Chen YF, Beach SR, Philibert RA, Kogan SM. Participation in a family-centered prevention program decreases genetic risk for adolescents' risky behaviors. Pediatrics. 2009;124(3):911-7.

8. Rondón MA, Rodríguez VA. Algunos conceptos básicos para el cálculo del tamaño de la muestra. Univ Med. 2007;48(3):334-9.

\section{CONCLUSION}

We conclude that there is a high prevalence of HRBP among students from Cartagena, Colombia, the pattern being one in every eight students. The frequency of HRBP is higher in students $>15$ years of age; in males; in those who are not heterosexual; in those with a bad-to-average academic performance; and in those reporting a dysfunctional family. HRBP is a multidimensional public health problem that requires a comprehensive approach. More cross-sectional studies are needed to explore other individual, family, and contextual variables that may be associated with HRBP. Also, it is important to carry out longitudinal studies that bring to light the causality and impact of interventions in the promotion of healthy lifestyles and the prevention of HRBP among adolescent students.

9. World Health Organization. Regional Office for Europe. Wellbeing measures in primary health care: the DepCare Project. Report on a WHO Meeting [Internet]. Stockholm; 1998 [cited 2011 Aug 25]. Available from: http://www.euro.who. int/_data/assets/pdf_file/0016/130750/E60246.pdf

10. Rosenberg M. Society and the adolescent self-image. Princeton: Princeton University Press; 1965.

11. Morgan JF, Reid F, Lacey JH. The SCOFF questionnaire: assessment of a new screening tool for eating disorder. $\mathrm{Br}$ Med J. 1999;319(7223):1467-8.

12. Center for Disease Control and Prevention; Department of Health and Human Services. Youth risk behavior surveillance United States, 2005. MMMWR Morb Mortal Wkly Rep [Internet]. 2006 [cited 2011 Aug 25];55 Suppl 5. Available from: http://www.cdc.gov/mmwr/PDF/SS/ss5505.pdf

13. Ewing JA. Detecting alcoholism: the CAGE questionnaire. JAMA. 1984;252(14):1905-7.

14. Alcaldía de Medellín. Sistema de vigilancia epidemiológica sobre el uso indebido de sustancias psicoactivas, VESPA. Medellín: Alcaldía de Medellín; 1993.

15. Campo-Arias A, Oviedo HC, Cogollo Z. Internal consistency of a five-item form of the Francis Scale of Attitude Toward Christianity among adolescent students. J Soc Psychol. 2009;149(2):258-62.

16. Smilkstein G. The family APGAR: a proposal for a family function test and its uses by physicians. J Fam Pract. 1978;6(6):1231-9.

17. Gómez-Bustamante EM, Cogollo Z. Factores predictores relacionados con bienestar general en adolescentes de Cartagena, Colombia. Rev Salud Publica (Bogotá). 2010;12(1):61-70. 
18. Rueda-Jaimes GE, Díaz-Martínez LA, Ortiz DP, Pinzón C, Rodríguez Martínez J, Cadena LP.Validación del cuestionario SCOFF para tamizaje de trastornos del comportamiento alimentario en adolescentes escolarizadas. Aten Primaria. 2005;35(2):89-94.

19. Greenland S. Bayesian perspectives for epidemiological research. II. Regression analysis. Int J Epidemiol. 2007;36(1):195-202.
20. Núñez E, Steyerbert EW, Núñez J. Estrategias para la elaboración de modelos estadísticos de regresión. Rev Esp Cardiol. 2011;64(6):501-7.

21. STATA Data Analysis and Statistical Software. version 9.0. College Station: Stata Corporation; 2005.

\section{Acknowledgements}

This study was funded by the Research Vice-Rectory at Universidad de Cartagena (Act of commitment № 054-20069) and approved by Research Ethics Board (Act № 27, 28 April 2011). We would also like to thank Dr Adalberto Campo-Arias, psychiatrist and master in sexual and reproductive health, Research Director at the Human Behavior Research Institute, Bogotá, Colombia, for his help in data analysis; the student nurse of Universidad de Cartagena Andrés Beltrán and Yiris Pájaro for their support and collaboration in the information gathering and digitization process; and the Secretaría Distrital de Educación de Cartagena, Colombia for its support in accessing the city's educational institutions. 